\title{
PLURALITAS PEMAHAMAN AKAN IDENTITAS GEREJA KATOLIK Perkembangan Pembaruan Eklesiologi Gereja Katolik Roma
}

\author{
Fransiskus Purwanto
}

\begin{abstract}
:
The presence of the Franciscans and Dominicans in the XIII century had reshaped the ecclesiology on local Church. This new understanding has helped the Church to be more responsive to the need of the people of God and the signs of the times. Luther and the Reformation challenged the Catholic Church to find a new way of being Church. A Church that overemphazied its structure, laws and superior organization (societas perfecta) was deeply questioned. On the other hand, the Holy Spirit of renewal could not be contained by a single reformation. The development in Patristic studies, Scriptures, lay movement, ecumenism as well as renewal in liturgy gave birth to a new ecclesiology that listens to the Holy Spirit seriously, and also the Scriptures as well as participation of the entire people of God as Christ's mystical body in building unity. These various movements of renewal will eventually be discerned and attended by the Second Vatican Council.
\end{abstract}

Kata-Kata Kunci:

Pluralitas, Identitas Gereja, Eklesiologi, warisan, tradisi.

\section{PENGANTAR}

Peringatan 50 tahun Konsili Vatikan II sudah berlalu. Banyak karangan telah membicarakan berbagai kenyataan eklesial yang terjadi diberbagai daerah. Muncullah bermacam-macam tanggapan positif dan negatif dari berbagai unsur Gereja. Berbagai gerak pembaharuan di dalam Gereja lahir, antara lain seperti gerakan karismatik, gerakan pembaharuan pastoral di keuskupan-keuskupan, gerakan Opus Dei, gerakan NeoCathecumenat, devosi-devosi populer, devosi marial, devosi-devosi kepada orang kudus dlsb. Selain itu, lahir pula refleksi-refleksi teologis yang beraneka ragam, antara lain teologi tentang pembebasan, teologi kemakmuran, teologi inkulturasi, teologi dialog, teologi Minjun, teologi Dalit, teologi ditengah sekularisasi, dlsb.

Pembaharuan-pembaharuan tersebut merupakan salah satu buah dari keputusan-keputusan Gereja yang diambil pada Konsili Vatikan II. Namun demikian, pergulatan Gereja untuk menjawab kebutuhan umat secara eklesiologi sudah berkembang sejak kelahiran Gereja ditengah bangsa-bangsa. Muncul sebuah pertanyaan penting: apakah pembaharuan setelah Konsili Vatikan II sungguh sesuatu yang serba baru? Tulisan ini mencoba untuk mempelajari secara lebih umum perkembangan eklesiologi Gereja Katolik ${ }^{1}$ yang dapat dijadikan kunci untuk memahami kenyataan eklesial saat ini.

\section{WARISAN PEMBAHARUAN EKLESIOLOGI GREGORIUS VII}

Jika kita berbicara tentang pembaruan eklesiologi pada Konsili Vatikan II (1962-1965), pembaharuan ini memiliki latar belakang yang kompleks dan panjang yang telah berlangsung berabad-abad. Salah satu titik penting dalam eklesiologi Gereja katolik Roma adalah pembaharuan Gereja sejak zaman Gregorius VII (abad IX-XII) ${ }^{2}$. Pembaharuan itu bertujuan membebaskan Gereja dari cengkraman kuasa para bangsawan awam. Pada zaman itu, para bangsawan masih menguasai tanah-tanah yang telah mereka serahkan kepada Gereja. Sebagai akibatnya, mereka mengangkat para imam atau uskup menurut kehendak mereka. 
Sementara itu, banyak imam menyalah gunakan wewenang eklesiastik (simonis) dan semakin banyaknya imam mengadakan pelayanan tanpa dasar panggilan yang kokoh. Banyak imam hidup dengan istri dan anak-anaknya (nicolaïsme); semua itu terjadi pada zaman dimana para imam secara teoritis memegang teguh selibat.

Usaha untuk memperoleh kebebasan Gereja dalam tataran klerikal, dilaksanakan oleh kepausan dalam kerjasama dengan gerakan pembaharuan monastik, khususnya dari Cluny. Sudah sejak abad sebelumnya, berbagai biara memperoleh suratsurat jaminan perlindungan dari kepausan yang mirip dengan sebuah pembebasan dari kuasa para uskup setempat. Kebiasaan ini terus berlanjut dan bertambah banyak setelah tahun 1000. Pembaharuan ini akan melindungi biara-biara dari dominasi kekuasaan-kekuasaan politik. Hal tersebut juga menghadirkan sebuah situasi Gereja supernational, yang didasarkan diri kepada monarki pontifikal, taat kepada kuasa mengajarnya. Dengan cara tersebut, gerakan Cluny menciptakan sebuah suasana yang mendukung bagi gagasan-gagasan eklesiologi para paus reformator ${ }^{3}$.

Untuk melaksanakan pembaharuan, kepausan menuntut kemandirian hukum bagi Gereja. Hal itu berarti bahwa Gereja mesti keluar dari hukum yang tercampur baur antara hukum para bangsawan dan hukum Gereja. Gereja menolak hukum yang simpang siur. Politik yang dilaksanakan oleh Roma demi kebebasan agama mengandaikan sebuah pandangan yang terang tentang transformasitranformasi yang sedang terjadi didalam masyarakat. Sementara itu, dari abad XI hingga XIII, masyarakat Eropa mengalami perubahan besar. Eropa menjadi semakin bersatu, populasinya bertambah menjadi dua kali lipat selama tiga abad, mobilitas warga masyarakat semakin banyak, kota-kota baru tumbuh dengan pesat, universitas-universitas terbentuk, dan lahir ordo-ordo religius baru.

Pada zaman ini, hukum kanonik berkembang pesat dan menempati fungsi penting bagi refleksi atas Gereja ${ }^{4}$. Jika hukum kanonik merupakan salah satu bidang ilmu, ia tidak tidak terlepaskan dari teologi. Guna membatasi kuasa-kuasa yang berkaitan dengan "imam" dan kekaisaran, para kononis akan mempergunakan konsep-konsep kuasa khususnya untuk mendefisikan bermacammacam pelayanan. Pendekatan ini akan mempengaruhi para teolog, yang sudah sejak lama memiliki dokumentasi sebagaimana dipergunakan oleh para kanonis.

Yohanes Gratien, rabih dari Bologna menulis Concordance des canons en desaccord. Buku ini merupakan sebuah koleksi teks kanonik yang disebut Decretum (1140) ${ }^{5}$. Ia menempatkan secara berdampingan teks-teks dari para ahli, sambil menghilangkan kekhasan dari masing-masing situasi dan jaman yang berbeda. Dengan cara tersebut, karya tersebut tetap menyimpan tematema eklesiologi tradisional yang sekiranya akan dilupakan pada jaman itu. Pada saat yang sama, metodenya bertujuan untuk memberi suatu kekuatan bagi sebuah norma tanpa hubungan dengan situasi aslinya.

Dalam alur pembaharuan Gregorian, Gratien mendorong bagi terciptanya sebuah hukum yang otonom bagi Gereja. Paus, dengan gelar vicarius Petri, secara definitif adalah satu-satunya pembuat undang-undang dalam Gereja. Tahta apostoliklah yang mengundang konsili-konsili. Sebuah tesis tentang kemungkinan bagi seorang paus heretik ditolak pada abad XII, khususnya oleh para kanonis. Gratien mengutip juga teks-teks dari Cyprianus, Agustinus, Gregorius Agung tentang peran kebiasaan, kekuasaan untuk melepaskan dan mengikat yang diberikan oleh Gereja dan bukan hanya kepada Petrus, dimana pelaksanaannya dirumuskan dalam bentuk hukum-hukum ${ }^{6}$.

\section{WARISAN EKLESIOLOGI FRANSISKAN DAN DOMINIKAN}

Pembaruan Gregorius ini menghantar angin segar di dalam Gereja. Keteraturan mulai terwujud. Abad XII membawa pembaharuan baru dengan lahirnya Ordo Fransiskan dan kan $^{7}$. Ordo Fransiskan lahir untuk membaharui Gereja dengan menawarkan cara hidup serius dengan menekankan sikap lepas bebas dari kekayaan dan hidup dalam komunitas. Gerakan ini lahir di Italia. Ordo Dominikan lahir untuk membaharui Gereja dengan menawarkan cara hidup yang dibaktikan bagi pewartaan iman yang benar sesuai dengan ajaran Gereja. Gerakan ini lahir di Prancis untuk melawan heresi Caharisme.

Peristiwa kelahiran OFM dan OP membawa perubahan eklesiologi yang cukup signifikan ${ }^{8}$. Jika sebelumnya, keuskupan dan para imam diocesan menjadi titik tumpu pastoral, kini muncul fenomena baru akan pastoral lintas keuskupan. Disatu pihak, hal ini akan lebih meneguhkan aspek katolisitas (Gereja yang tidak dibatasi oleh daerah-daerah tertentu), namun dilain pihak, kehadiran dua ordo ini mengoyahkan kemapanan yang ada. Mereka tidak tunduk kepada pimpinan Gereja lokal tetapi tunduk kepada paus.

Yang menjadi penyebab ketegangan adalah persoalan disekitar wilayah dan pengaruh ordo- 
ordo baru dan para imam diosesan. Persoalannya berkaitan dengan pemahaman tradisional tentang Gereja sebagai communio Gereja lokal. Dengan mencangkokkan diri secara langsung dengan kepausan, ordo-ordo baru memberi bentuk baru bagi persoalan keanggotaan katolisitas : tanah air spiritual mereka bukan lagi Gereja lokal tapi Gereja universal. Disamping Gereja-Gereja yang terikat dengan stuktur-struktur feodal dan dengan tempat-tempat tertentu, anggota ordo-ordo baru menghadirkan sebuah dimensi "missioner», mobilitas, dan Gereja universal. Pada saat yang sama, mereka memperkuat pengaruh kepausan dan memberi gambaran bagi sebuah keuskupan universal.

Ordo-ordo para pengemis dikemudian hari akan dekat dengan universitas-universitas, sebuah tempat baru bagi kaum intelektual kristiani, yang dikemudian hari mereka akan memiliki reputasi international. Berhadapan dengan tempat-tempat intelektual tersebut, kuasa mengajar para uskup lokal tampak sedikit kewalahan untuk mengaturnya, sementara kepausan semakin menampakkan diri semakin kuat dan dapat menyelesaikan persoalan-persoalan. Sejak tahun 1231, berdasarkan contoh dari Universitas Paris yang mendasarkan diri kepada hak istimewa dari paus, universitas-universitas baru memohon diteguhkan oleh Roma.

\section{WARISAN EKLESIOLOGI ABAD XIII-XVI}

Pada abad $\mathrm{XII}^{9}$, masalah utama eklesiologi Gereja Latin berkisar diantara persoalan kuasa paus berhadapan dengan kuasa para pangeran. Sementara itu, pengajaran teologi saat itu terus melanjutkan tradisi pemahaman atas kenyataan eklesial berdasarkan inspirasi KS dan para Bapa Gereja, khususnya dengan gambaran Tubuh mistik. Tema Tubuh mistik juga memiliki konotasi bertipe corporatif, yang dengannya kepala mempresentasikan seluruh tubuh, kepala sebagai yang meringkaskannya ${ }^{10}$.

Jauh dari perdebatan-perdebatan yang berkaitan dengan kekuasan paus dan para pangeran, teologi Abad Pertengahan ini mencerminkan sebuah kesadaran Gereja dalam konteks sejarah kemanusiaan seluruhnya. Kristus menempati peran sentral dalam seluruh teologi. Gereja terhimpun dari keseluruhan ciptaan spiritual yang memiliki rahmat. Yang menjadi anggota Gereja " dimana kita adalah anggotanya » (St. Thomas memberikannya secara detail), para malaikat dan para kudus dari Perjanjian Lama. "Sejak Habel yang saleh », hingga Kristus, mereka semua dibenarkan oleh iman dalam kerinduan akan kedatangan Kristus dan membentuk Gereja yang telah mendahului kita (Bonaventura). Di zaman Perjanjian Baru, yang menjadi anggota Gereja adalah para kudus di surga dan juga orang-orang suci di atas bumi, artinya semua orang yang hidup dalam iman dan cinta kasih. Juga jiwa-jiwa di tempat penantian, yang dalam arti tertentu masih berada di dunia, menjadi bagian dari Tubuh Kristus. Bagi orang kristani yang berdosa dan tidak hidup dalam rahmat, mereka adalah " para anggota yang mati » atau «mereka yang tidak sempurna ", atau menurut pembagian kuno, mereka tetap menjadi anggota Gereja berkat « keanggotaan mereka» dan bukan karena « keadaan mereka ». Seperti pada abad sebelumnya, Tubuh mistik Kristus hidup dan disatukan berkat makanan Tubuh Ekaristi. Sebagaimana diungkapkan oleh Thomas, "res » dari ekaristi (realitas akhir yang dinyatakan oleh sakramen ekaristi) adalah kesatuan tubuh mistik ${ }^{11}$.

Pada peralihan abad XIII dan XIV, mulai terbentuklah sedikit demi sedikit traktat yang membicarakan Gereja sebagai sebuah masyarakat yang terorganisir dan kasad mata, dan pembicaraan tentang Gereja tidak lagi hanya sebagai bagian kecil dalam traktat kristologi. Karya-karya eklesiologi pada masa ini belum merupakan sebuah kesatuan ajaran yang lengkap tentang Gereja. Teologi hirarkis dari primat kepausan tampak secara ekstrim dalam bulla Unam Sanctam (18 nov 1302) yang disyahkan oleh paus Bonifasius VIII (1294-1303) dalam sebuah perdebatannya dengan raja Phillipe IV Le Bel. Inilah rumusannya yang khas :

Gereja katolik satu-satunya Gereja, tanpa dia « tidak ada keselamatan dan tidak ada juga pengampunan dosa-dosa ». Gereja hanya memiliki satu tubuh, satu kepala dan tidak memiliki dua kepala bagaikan monster: «Kepalanya adalah Kristus dan Petrus, wakil Kristus, dan penerus Petrus ». «Sabda Injil mengajarkan kepada kita: kekuasaan ini meliputi dua belah pedang yakni spiritual dan temporal [...]. Keduanya berada dalam kekuasan Gereja, mata pedang spiritual dan material. Akan tetapi kekuasaan material tersebut harus dilaksanakan demi Gereja, sedangkan yang spiritual dilaksanakan oleh Gereja. Yang spiritual dilaksanakan oleh para imam, yang lain oleh para raja dan pangerang dengan persetujuan dan kesesuai dengan para imam [...] Kebenaran telah menyatakan: kekuatan spiritual dapat membentuk kekuatan duniawi dan mengadilinya jika ia tidak baik [...] Barang siapa 
yang melawan kekuatan tersebut yang telah ditetapkan oleh Allah «melawan hukum Allah » (Rm 13,2). Dengan demikian, kami menyatakan, memutuskan dan mendefinisikan bahwa sangatlah perlu bagi keselamatan semua ciptaan manusiawi untuk tunduk kepada Pontif Roma » ${ }^{12}$.

Rumusan tersebut mengambil alih pandangan paus Gregorius VII, Innocentius IV dan para teolog jaman itu. Arti teks tersebut mesti ditafsirkan dalam konteks zamannya. Kalau kita mengartikan secara tekstual, pernyataan-pernyataan tersebut amat mengejutkan : Kristus dan paus merupakan satu kepala, dengan demikian, paus dengan Kristus-adalah kepala tubuh mistik.

\section{WARISAN EKLESIOLOGI REFORMASI DAN KONTRA REFORMASI}

Eklesiologi Gereja katolik memperoleh goncangan besar pada abad XVI dengan pembaharuan Luther dan Calvin ${ }^{13}$. Keberatan-keberatan yang diajukan oleh Luther dapat ditempatkan dalam arus besar pembaharuan Gereja yang melawan kecenderungan absolutisme pembaharuan abad XII; skandal yang terlalu mengagungkan para gembala (baik dalam pengajaran maupun sikapnya); institusi Gereja yang cenderung menjadi kaku dan kurang memperhatikan dina-mika Roh Kudus dan Rahmat. Institusi Gereja dianggap telah mengaburk rahmat keselamatan Allah yang Cuma-Cuma dan iman yang murni yang diberikan dalam Kitab Suci.

Para Reformator menggarisbawahi bahwa Gereja Kristus yang benar tidak dapat diidentifikasikan dengan institusi manusiawi yang tidak sempurna. Gereja merupakan keseluruhan orangorang beriman; mereka menghidupi iman mereka dalam rahmat keselamatan Allah yang diberikan oleh Yesus Krisus dan disampaikan oleh Roh Kudus. Gereja seperti itu, tidak dapat dengan mudah dilokalisir, Allah sendiri yang tahu. Calvin berbicara tentang Gereja yang tak tampak, Luther berbicara Gereja yang tersembunyi. Melachton membedakan antara Gereja fenomenal, extern dan tampak dengan Gereja yang benar, batiniah dan tak tampak. Dalam keberadaan kristiani, satusatunya otoritas adalah Allah dan SabdaNya. Otoritas gerejawi menyatakan kepentingan-kepentingan manusiawi dan praktis.

Gereja adalah persekutuan para kudus, dimana Injil diajarkan dalam keasliannya dan sakramen-sakramen dilaksanakan sesuai peraturan. Supaya terdapat sebuah kesatuan
Gereja yang sesungguhnya, cukuplah untuk menyetujui ajaran Injil dan pelayanan sakramen-sakramen. Tidaklah perlu bahwa dimana-mana terdapat tradisi manusiawi atau ritus dan perayaan serta institusi manusiawi yang sama: demikianlah yang dikatakan Paulus: "satu iman, satu baptisan, satu Tuhan dan Bapa semua orang”14.

Berhadapan dengan kritik ini, Gereja katolik mengembangkan sebuah eklesiologi yang ditandai dengan sifat apologetik, yuridis dan spekulatif. Hal yang amat menarik berkaitan dengan kritikkritik para reformator, reaksi-reaksi tidak datang dari pihak kepausan. Beberapa paus bersemangat dalam mengadakan pembaharuan-pembaharuan di dalam Gereja, misalnya Adrian VI (1522-1523). Ia teringat akan pengajarannya di Louvain, dimana ia mengakui bahwa pada masa yang silam "para paus telah bersalah" dan dimana ia menolak sebuah ketaatan tanpa syarat. Ia merekomendasikan kepada para utusannya untuk mengakui kesalahah Gereja mulai dari kesalahan tahta suci.

Dalam bidang dogmatik, jawaban atas kritikkritik reformator disuarakan oleh Konsili Trente (1545-1563). Sekilas, konsili ini tidak akan membicarakan eklesiologi, juga tidak membicarakan paus. Kebisuan ini disebabkan oleh berbagai alasan. Objektif utama dari konsili adalah pembaharuan Gereja dan tidak berkaitan dengan persoalan eklesiologis tetapi berkaitan dengan persoalan rahmat dan pembenaran. Berkaitan dengan struktur Gereja, para Bapa Konsili Trente mewariskan kasanah eklesiologi yang tersebar: pandangan papalist; pandangan yang berasal dari aliran spiritual; pandangan konsiliarisme. Para Bapa konsili Trente (uskup sebagai peserta dan para teolog hanya berfungsi sebagai penasehat) justru kawatir jika pandangan mereka malah akan semakin memperkokoh kekuasan kuria romana atau kekuasaan para pangeran.

Jikalau konsili Trente tidak mengambil sebuah keputusan berkaitan dengan kepausan, namun konsili membela keberadaan struktur hirarki Gereja, yang secara radikal diragukan oleh para Reformator. Dalam session 4 (8 april 1546), konsili menentang pandangan sola sriptura yang menjadi sumber iman. Konsili menyatakan bahwa Gereja menerima Kitab Suci dan Tradisi “dengan hormat yang sama"15. Tanpa masuk dalam pembicaraan tentang hubungan antara keduanya, konsili membedakan dengan jelas antara Tradisi apostolik dan tradisi eklesiastik, yang menjadi bahan kesalahan dan pelecehan. Tradisi autentik dicirikan dengan keberlangsungan historis dari penerusan dan penerimaan secara terus menerus di 
dalam Gereja. Dengan cara itu, konsili tidak melupakan peran konsensus Gereja bagi penerusan yang setia dari pewahyuan, dan juga tidak melupakan Roh Kudus yang senantiasa menyertai Gereja.

Reaksi Gereja Katolik atas kritikan para Reformator melahirkan aborasi pembahasan tentang Gereja dalam arti teologis. Jawaban kepada para Reformator, secara prinsipal diberikan oleh Robert Bellarminus (1542-1621). Bukunya Controverses (terbit antara 1586 dan 1593) sangat mewarnai Gereja katolik hingga abad XX. Ia berpijak pada keprihatinan utama untuk memperkuat pokokpokok kontroversi, dengan menekankan segi kelihatan dari Gereja dan kekuasaan paus, guna menunjukkan unsur internal dan communio iman.

Definisi tentang Gereja dari Bellarminus merupakan komentar atas pengakuan iman katolik yang diminta oleh Pius IV, 1564: «Saya mengakui Gereja kudus, katolik dan apostolik dari Gereja Roma sebagai ibu dan guru dari GerejaGereja, saya berjanji dan berjanji untuk taat kepada paus di Roma, pengganti Petrus, pangeran dari para rasul dan Wakil Kristus ${ }^{16}$ ". Komentarnya:

Hanya ada satu Gereja, dan bukan dua. Satusatunya Gereja yang benar adalah persekutuan orang-orang yang dipersatukan oleh pengakuan iman kristiani yang sama dan dalam communio sakramen-sakramen, dibawah pengembalaan para imam yang syah dan khususnya dibawah satu-satunya Wakil Kristus dimuka bumi ini yakni paus.

Definisi ini sangat menekankan aspek kelihatan. Komentarnya tentang arti persekutuan orangorang :

Supaya seseorang dapat dikatakan sebagai bagian dari Gereja yang benar [...] tidak satu keutamaan batiniah pun dibutuhkan, menurut pendapat kami, hanya pengakuan iman ekternal dan komunitas sakramen-sakramen, sesuatu yang dapat dipahami oleh indra. Dengan demikian, Gereja adalah sebuah persekutuan orang-orang yang kelihatan dan bercirikan kepausan yakni baik yang dikumpulkan sebagai umat romawi atau kerajaan Perancis atau Republik Venezia ${ }^{17}$.

Tekanan kepada keanggotaan dari Gereja yang kelihatan berakibat kepada pembedaan didalam Gereja antara «tubuhnya » yang kelihatan, yang berisi «notes ecclesiae» (satu-kuduskatolik-apostolik $^{18}$ ) yang dapat menjadi ukuran Gereja yang sebenarnya dan untuk membedakan
Gereja yang salah, dan "jiwanya » yakni hidup rahmat yang menjiwai Gereja.

Karya Bellarminus tersebut diatas sangat teliti dan cermat. Bukunya ini dicetak berulang kali (16 kali edisi antara 1586-1608). Namun demikian tidak semua karya Bellarminus diikuti oleh semua orang $^{19}$. Selain Bellarminus, sebuah sekolah teologi dominikan dan Karmel di Salamanca mendasarkan refleksi mereka kepada Summa theologia Thomas Aquino. Mereka melanjutkan pembicaraan tentang Tubuh Mistik Kristus dalam konteks kristologi. Beberapa teolog membahas eklesiologi dengan memberi komentar atas pertanyaan sbb: "apakah peran tahta suci diamanatkan dalam symbol iman (II-II, q.1, a.10) - yang membicarakan tentang Gereja melalui bias dari magister paus.

Banyak ahli mengatakan bahwa pendekatan Bellarminus memiskinkan sensibilitas eklesiologi. Yang banyak dibicarakan: keanggotaan Gereja, ciri-ciri Gereja, infallibilitas Gereja dan hirarkinya, uskup dan primat paus. Namun kita tidak akan menemukan sedikit pun pembicaraan tentang Gereja lokal, persekutuan para kudus, imamat kaum beriman dan kharisma-kharisma. Dengan demikian, teologi pasca Trente ikut menyebar luaskan sebuah gambaran Gereja yang sangat institutional. Gereja adalah masyarakat sempurna artinya, dalam dirinya, Gereja memiliki seluruh sarana yang diperlukan untuk menghantar seluruh anggota-anggotanya kepada tujuan akhir diadakannya Gereja. Gereja itu sendiri adalah kriteria tetap untuk mendefinisikan isi iman dan penafsiran KS. Semboyan kuno : «Diluar Gereja tidak ada keselamatan ", sering dipergunakan sesuai dengan situasi jaman itu: siapa yang menjadi anggota Gereja ? Apakah para pendosa, para heritik, para skismatik juga termasuk anggota Gereja ? Jawaban para teolog sangat bervareasi, namun akhirnya semuanya akan dijawab dalam hubungannya dengan institusi : orang akan diselamatkan dengan menjadi anggota Gereja yang benar, sebagai satu-satunya sarana yang dikehendaki Allah untuk keselamatan semua orang.

\section{WARISAN EKLESIOLOGI ABAD PENCERAHAN}

Pada abad XVII, ilmu filsafat telah menyadari sifat khasnya terlepas dari pewahyuan dan hal-hal ilahi. Setelah itu, pada abad XVIII, dengan perkembangan metode kritik sejarah dan biblis, dengan munculnya konflik religius, muncullah bentuk-bentuk keraguan iman dalam masyarakat $^{20}$. Patokan-patokan umum yang sudah men- 
jadi warisan nenek moyang mulai direlativir. « Kelompok-kelompok masyarakat tercabut dari akarnya dan berkeliaran menyeberangi batas-basa sosial dan simbolik lebih terbuka kepada halusinasi tukang sihir daripada menciptakan kekosongan. Sikap skeptis yang muncul mencerminkan kekosongan, khususnya dikalangan para terpelajar ${ }^{21}$. Agama tidak ditolak mentahmentah. Orang menyadari peran agama sebagai pendidik dan proses humanisasi. Akan tetapi, berdasarkan titik pandang tersebut, tidak ada alasan a priori untuk mengistimewakan sebuah agama. Semua agama pada prinsipnya adalah sama, ajaran-ajaran mereka sangat berguna bagi kebaikan moral.

Salah satu tokoh penting pada masa ini Immanuel Kant (1724-1804). Ia menyebut jaman itu sebagai jaman kritis. Dalam sistem filsafatnya, ia menempatkan eksistensi Allah adalah sebuah postulat dari ratio praktis. Selain filsafat kristiani, muncul juga gerakan Frank-Masoneri (kelompok anti klerikal dan anti Gereja), yang menjadikan deisme ini sebagai dasar tumpuan kelompok. Pada akhir abad XVIII diproklamasikanlah hak-hak dasar manusia dalam Deklarasi Kemerdekaan Amerika (1776) dan Konvensi Nasional Perancis (1789). Sebagai akibat dari Revolusi Prancis, Gereja katolik mengadakan restorasi yang akan terjadi pada abad XIX. Dengan dirampasnya hakhak istimewa Gereja katolik dan dengan lahirnya pemerintahan yang memisahkan antara negara dan Gereja, Gereja harus meninggalkan ketergantungannya kepada kekuasaan sekular dan memusatkan diri dalam perutusannya yang sejati.

Terpengaruh oleh polemik anti protestan, eklesiologi katolik menjadi sangat sempit ketika berbicara tentang Gereja. Gereja hanya dipandang sebagai institusi yang tampak secara hirarkis. Gereja memiliki hirariki sebagai penjaga yang berotoritas. Dalam konteks jaman Pencerahan, pemiskinan eklesiologi semakin kentara pengaruhnya. Bagi orang-orang yang terdidik, Gereja secara essensial diasosiakan dengan ibadah, didasarkan pada prinsip hukum kodrat, bermanfaat bagi masyarakat karena Gereja adalah pendidik dalam arti moral. Didirikan oleh Yesus Kristus, tersusun rapi secara hirarkis, Gereja adalah sebuah institusi publik yang bertugas mendidik agama; Gereja bertugas untuk menjaga kasanah dan menyebarluaskannya. Gereja melaksanakan peran tersebut melalui tindakan ibadah dan praktek kehidupan. Tentunya, dalam konteks seperti itu, para pelayan ibadah memiliki tempat yang istimewa, umat sebagai penerima harta rohani dilayani oleh mereka. "Yang dirasakan bukan menjadi Gereja, tetapi taat kepada Gereja ${ }^{22}$ » Gagasan ini tampak juga dalam katekismus pada jaman itu. Pada tahun 1823, Adam Möhler meringkaskan eklesiologi dengan sinis : "Allah menciptakan hirarki, dan ia menjamin keberlangsungan Gereja hingga akhir jaman ${ }^{23}$

Kehidupan sehari-hari komunitas kaum beriman tidak hanya tercermin dalam diktat-diktat atau perdebatan-perdebatan teologis yang sedang hangat dibicarakan. Pada abad XVII dan XVIII muncul juga berabagai perkumpulan umat kristiani, kelompok penyembah Sakramen Mahakudus dan kongregasi-kongregasi marial, reevangelisasi di kampung-kampung dan ibu-ibu katekis yang memerankan pewartaan tiada henti. Kehidupan kristiani terus berlangsung dan mengalami kebangkitan, Terdapat juga perkembangan kehidupan rohani dan mistik. Dalam hubungannya dengan bermacam-macam Gereja kristiani, toleransi pelan-pelan terjalin. Pada abad XIX, muncullah sebuah vitalitas yang amat besar dalam hal devosi-devosi dan juga karya missi. Perkembangan kehidupan komunitas ini merupakan mata air bagi pembaharuan eklesiologi dikemudian hari.

\section{WARISAN PEMBAHARUAN EKLESIOLOGI ABAD XIX}

Pembaharuan eklesiologi yang cukup penting lahir pada abad $\mathrm{XIX}^{24}$. Aliran yang pertama tampak khususnya di Italia dan Perancis. Aliran ini cenderung membela kepausan dan institusi Gereja katolik. Gereja diidentifikasikan secara total dengan struktur yuridis dari pemerintahnnya ; Gereja selalu berciri kerajaan hingga hari ini ; ia memiliki kebal-salah karena paus, pemimpinnya adalah kebal-salah. Mauro Cappellari (Gregorius XVI (1831-1846)), seorang rahib dari Camaldule menerbitkan sebuah buku : Le triomphe du SaintSiège et l'Eglise (Kejayaan tahta suci dan Gereja).

Di Perancis, kekuasaan paus diperteguh berkat beberapa penulis tradisionalis yang amat berbakat, Louis de Bonald (1745-1840), Joseph de Maistre (1753-1821) dan Félicité de la Mennais (17821854). Mereka ini adalah pendukung aliran ultramontanisme. Joseph Maistre, dalam bukunya $d u$ Pape, menulis: infallibilitas dalam tataran rohani, dan kekuasaan tertinggi dalam tataran duniawi adalah dua hal synonim secara sempurna $^{25}$ ». Kecenderungan ultramontanisme terdapat juga dalam diri para teolog dan kanonis Jerman, Italia dan Spanyol dari abad XIX. Mereka tidak mengkritik kepausan, melainkan hanya 
mengaffirmasi saja. Pada saat yang bersamaan, mereka turut serta menyebarluaskan ideologi Gereja sebagai monarki pontifikal, sebuah ideologi yang akan berpengaruh dalam konsili Vatikan I (1869-1870).

Aliran kedua adalah aliran teologi yang mencoba membaharui Gereja bukan dengan merestorasi kekuasaan, tetapi dengan menemukan kembali inspirasi dari sumber-sumber patristik dan Abad Pertengahan. Gerakan ini terpaut dengan sebuah gerakan kebudayaan lebih luas yakni romantisme. Mereka mengedepankan kembali nilai tradisi, khususnya sebuah gambaran yang terlalu diidealisir dari Abad Pertengahan. Mereka menyanjung nilai-nilai batiniah dari perasaan. Sebuah pandangan baru tentang Gereja akan muncul dalam suasana baru, yang terkait erat dengan eklesiologi para Bapa Gereja. Mereka membawa warna baru dalam teologi, pastoral dan katekese, juga seni Gereja yakni gaya romawi baru atau gaya gothik baru. Mereka memusatkan diri pada refleksi tentang Allah yang menyejarah sebagaimana dikisahkan dalam Injil, dan peran pokok dari Kristus dalam sejarah keselamatan.

Pandangan ini memprioritaskan gagasan Gereja sebagai «umat Allah », sebagai sebuah kolektivitas yang terbentuk dan yang percaya secara organis sepanjang sejarah, yang dibimbing oleh hidup yang penuh kekayaan bagaikan sebuah gerakan total yang mempersatukan kesatuan dan pluralitas. Aliran ini diperkaya oleh beberapa nama besar : Johann Michael Sailer (1751-1832), Johann Sebastian Drey (1777-1853) dan Johann Adam Möhler (1796-1836). Di England, John Henry Newman (1801-1890) membawa pandangan baru tentang Gereja yang melampaui Abad Pertengahan, dan dikaitkan dengan Patristik.

Sementara kembali ke sumber Biblis dan Bapa Gereja, para teolog Tübingen memberi perhatian yang besar bagi Gereja sebagai totalitas organisme yang hidup. Obyek eklesiologi adalah hidup Gereja. Gereja dipahami bukan pertama-tama sebagai sebuah masyarakat yang tampak dan tersusun secara hirarkis, tetapi sebagai sebuah " komunitas hidup ", tempat dimana Rahmat berkarya, Roh Kudus bekerja menyalurkan penyelamatan melalui Yesus Kristus. Dengan hadirnya Roh Kudus yang bertindak, Gereja merupakan communio yang terbentuk dalam iman dan kasih. Institusi merupakan artikulasi-artikulasi yang tampak, yang berfungsi untuk melaksanakan kebaikan bersama.

Eklesiologi Möhler berpengaruh dalam eklesiologi Tubuh Mistik mulai tahun 1920.
Möhler menemukan kembali Bapa Gereja dengan anthusiasme yang besar, dan kesadaran mendalam akan kegembiraan abadi dari Gereja perdana. Menurutnya, prinsip mendasar dari hidup menggereja bukanlah strurktur hirarki. Sebelum semuanya itu, Roh Kudus, jiwa Gereja, dari dialah mengalir seluruh hidup. Gereja adalah «hasil yang tampak dari kekuatan batiniah, tubuh dari roh yang menciptakan dirinya sendiri ». "Individu, sebagai bagian dari keseluruhan organisme, berdasarkan Allah, tidak akan mengenal Allah kecuali dalam keseluruhan ». Rohlah yang mempersatukan Gereja sebagai organisme yang hidup dan menghadirkan prinsip permanen identitasnya. Roh adalah motor batin dari perkembangan dan perluasannya, Dialah yang bertindak didalam Gereja, Dialah yang melahirkan dalam dirinya berbagai fungsi yang Gereja perlukan. Uskup menghadirkan faktor kesatuan dalam keuskupannya, uskup metropolitan menghadirkan kesatuan dari beberapa keuskupan, paus menghadirkan kesatuan bagi Gereja semesta. Tekanan pneumatologis, yang terdapat dalam bukunya L'unité de L'eglise ou le principe du catholicisme (1825), akan semakin seimbang dengan unsur kristologis dalam bukunya Symbolique (1832). Sebagai kelanjutan inkarnasi Sabda Allah dalam waktu, Gereja merupakan penampakan tetap, bercirikan ilahi dan manusiawi; Gereja adalah kesatuan dari kedua sifat tersebut ${ }^{26}$ ». Dengan demikian, kita berada jauh melampaui eklesiologi Aufklärung.

\section{PEMBAHARUAN EKLESIOLOGI KONSILI VATIKAN I}

Dikumpulkan dalam konteks konfrontasi antara Gereja dan dunia modern, konsili Vatikan I bermaksud untuk «mempersatukan dunia katolik dibawah satu kekuatan untuk menunjukkan kebenaran, diperlawankan dengan kesalahan jaman itu " dan untuk memperkuat otoritas eklesiastik, khususnya kepausan ${ }^{27}$. Demi tujuan ini, konsili berusaha pertama-tama untuk memperteguh identitas Gereja, otonomi dan hakhanya sebagai societas perfecta. Menghadapi kekeliruan modernisme, Gereja menggarisbawahi berkali-kali otoritas Gereja sebagai pengajar dengan menyebutnya sebagai "penjaga dan guru dari Sabda Allah”.

Perdebatan-perdebatan selama konsili mencerminkan kekhasan eklesiologi pada masa itu. Terdapat dua kecenderungan teologi: mereka yang mendapatkan darah dan sumbernya dari patristik dan mereka yang menekankan otoritas pontifikal. Schema De Ecclesia (teks januari 
1870) berbicara tentang Gereja sebagai tubuh mistik Kristus. Titik pijak ini ditolak oleh mayoritas Bapa konsili yang dibentuk dalam teologi Bellarminus yang mendefinisikan Gereja sebagai sebuah societas yang kelihatan dan tersusun secara hirarkis. Menurut mereka, gagasan tentang tubuh mistik Kristus mirip protestan atau jansenis. «Tubuh Kristus » dipamahi dalam tradisi agustinus sebagai rahmat yang mengalir dari Kristus kepada kepada kumpulan individuindividu. Para Bapa konsili menghendaki sebuah definisi tentang Gereja berdasarkan unsur-unsur eksternal. Teks yang direvisi tetap mempertahankan gagasan Tubuh mistik akan tetapi dengan mengarisbawahi Gereja sebagai sungguhsungguh societas. Konsili yang ditutup secara mendadak mengakibatkan pembahasan schema $D e$ Ecclesia tidak dilanjutkan.

Konsili Vatikan I tidak berbicara tentang hakekat dan identitas Gereja secara komprehensif. Teks Pastor aeternus hanya memberi beberapa modalitas yang amat rinci tentang kekuasan paus : hak paus untuk berkomunikasi secara bebas dengan para uskup, hak untuk naik banding kepada paus untuk hal-hal yang menyentuh yuridiksi eklesiastik, dengan diingatkan bahwa «tidak ada seseorang pun yang berhak untuk menilai keputusan paus ». Konsili Vatikan I menolak konsiliarisme. Anathemasit final mengatakan:

Jika seseorang mengatakan bahwa pontif Roma hanyalah memiliki tanggungjawab inspeksi atau hanya mengarahkan dan tidak memiliki kuasa penuh dan yuridiksi tertinggi atas seluruh Gereja, bukan hanya yang berkaitan dengan imam atau kesusilaan, tetapi juga yang berkaitan dengan peraturan dan pemerintahan Gereja tersebar diseluruh dunia, atau ia hanya memiliki sebagian penting dan bukan totalitas dari kekuasaan yang tertinggi, atau kekuasaan itu bukanlah kekuasaan yang biasa dan langsung atas seluruh dan setiap orang dari gereja-gereja, sama seperti bagi seluruh dan setiap gembala dan setiap umat, terkutuklah (DzS 30603064).

Perdebatan selama konsili berhasil merumuskan keseimbangan baru dalam teks yang sebelumnya sangat unilateral. Intervensi tersebut memberi juga batasan-batasan terhadap obyek ajaran. Ajaran tentang infallibilitas tersurat dalam koherensi yang sama dengan soal primat: paus memiliki karisma infallibilitas dalam situasi yang jelas, sangat terbatas, sebagaimana diindikasikan dalam rumusan konsili. Keistimewaan paus ini adalah khas, hal ini tidak hanya sama dengan infallibilitas Gereja. Dan jika paus mempertimbangan Tradisi, hal ini tidak dapat dikatakan sebagai sebuah prasyarat mutlak yang harus diadakan tetapi hal tersebut merupakan sebuah kenyataan yang biasa terjadi dan wajar. Objek dari infallibilitas sangat jelas: fides et mores (iman dan kesusilaan). Demikian juga, diperlukan syarat lain yakni paus harus menyatakannya secara resmi artinya paus berkehendak secara eksplisit untuk mengungkapkan iman Gereja dan segala hal yang berkaitan dengan iman umat berkaitan dengan salah satu pokok iman. Itu semua merupakan bagian dari tugas dan tanggungjawab uskup Roma yang sejati : inilah arti dari kata ex cathedra.

Konsili Vatikan I mengandung beberapa kekurangan yang terkait dalam zamannya. Konsili ini sedikit sekali menyentuh hubungan antara paus dan seluruh umat Allah dan tidak menyinggung sedikit pun tentang sensus fidelium. Konsili yang berkeinginan menjadi konsili ekumenis tidak membicarakan sedikit pun tentang Gereja-Gereja yang lain. Kalaupun konsili mengundang GerejaGereja orthodoks dan Protestan, konsili mengundang mereka untuk kembali ke satu tempat yakni Gereja katolik. Tidak tampak juga ajaran tentang Roh Kudus secara eksplisit, juga tak tampak semangat missioner.

\section{PEMBAHARUAN MENJELANG KONSILI VATIKAN II}

Pada awal abad ke-20, Gereja, khususnya di Eropa Barat dilanda sebuah perubahan yang amat besar dalam seluruh aspek kehidupannya : teknologi, ekonomi, sosial dan kultural. Menurut A. Dondeyne (Leuven), saat itu sedang terjadi unifikasi dunia dalam seluruh aspek hidupnya ${ }^{28}$. Kemajuan ilmu pengetahuan dalam hal astronomi dan fisika serta kimia membawa pembaharuan yang besar dalam cara pandang manusia terhadap kosmos dan menggoyahkan pandangan kosmologi yang diyakini hingga saat itu. Kemajuan ilmu pengetahuan dan khususnya teori Einstein telah mendorong kemajuan yang besar didalam ilmuilmu modern. Sementara itu, ilmu biologi berkembang pesat berkat kemajuan penelitian-penelitian bagi kromosom, DNA dlsb. Penemuan-penemuan tersebut membawa pembaruan bagi pemahaman tentang evolusi manusia dan seluruh kosmos.

Berkat kemajuan teknologi, manusia semakin berkembang didalam penaklukannya terhadap alam semesta. Teknologi (khususnya mesin-mesin modern) telah mengintroduksir hubungan baru antara manusia dan alam. Kerja manusia memperoleh dimensi baru dengan bantuan mesin-mesin. 
Kemajuan mesin-mesin tersebut telah melahirkan masyarakat industri yang baru yang mengubah juga hubungan antar anggota masyarakat dan memunculkan soal-soal baru. Masalah urbanisasi menjadi semakin kompleks dibarengi dengan soal kemiskinan kaum buruh serta ketidak seimbangan ekonomi. Persoalan ini mengerucut didalam persoalan disekitar dunia kaum buruh dan soal keadilan.

Kemajuan teknologi telah membawa dua dampak yang ambigu: disatu pihak membawa kemajuan ekonomis dan politik yang membawa masyarakat semakin makmur dan mendorong kooperasi antar Negara-negara; dilain pihak hukum ekonomi telah melahirkan jurang kemiskinan yang semakin dalam antara Negara kaya dan miskin dan memunculkan kemiskinan dimana-mana, selain itu kenyataan Perang Dunia I dan II telah menunjukkan bahwa perkembangan tekno-logi dan ekonomi bukanlah satu-satunya ukuran perkembangan manusia. Sementara itu, organisasi-organisasi religius (Gereja) semakin tidak memberi jawaban yang dinantikan oleh perkembangan dunia modern (khususnya di Eropa).

Dalam bidang filsafat, banyak filsuf berefleksi tentang makna tragedy kemanusiaan khususnya Perang Dunia II dan masa depan dunia ini setelah kehancuran karena perang. Filsafat existential menempati tempat yang istimewa didalam refleksirefleksi filosofis setelah perang (S. Kierkegaard, M. Heidegger, K. Jaspers, JP. Sartre, Alb. Camus, M. Perleau-Ponty dlsb.) Dalam hal refleksi disekitar filsafat ketuhanan, kita dapat menemukan beberapa orientasi utama: atheisme praktis, agnotisme, atheisme, fideisme, integrisme dan progressisme. Sementara itu, Karl Marx dan F. Engel berkontribusi besar didalam kritiknya terhadap agama dengan menekankan otonomi manusia sambil menolak sebuah transendensi yang mengatur kehidupan manusia ${ }^{29}$.

Perkembangan-perkembangan diatas (kemajuan penelitian ilmiah, sosiologis, filosofis dan histories) amat mempengaruhi kehidupan Gereja katolik - yang sangat menekankan pentingnya sentralisasi (kepausan), Gereja dipandang sebagai societas perfecta, Gereja yang sangat diwarnai pengaruh hirarki. Dalam konteks ilmu gerejani, banyak teolog membuat penelitian-penelitan baru dan mencoba untuk menerapkan metode kritik sejarah dan litteratur bagi studi Kitab Suci dan sejarah Gereja serta studi teologi pada umumnya dan mencoba mendamaikan antara legimitas kuasa mengajar Gereja dan tuntutan bagi sebuah karya ilmiah dan otonominya ${ }^{30}$.
Hingga konsili Vatikan II, secara ringkas dapat dikatakan bahwa aliran teologi resmi Gereja katolik $^{31}$ (teologi yang yang dikontrol oleh otoritas gerejani, normative bagi pengajaran, kotbah dan katekese) dicirikan sbb:

- Teologi ini sangat mementingkan Tradisi yang membawa kepada kepastian, dimana Kitab suci tidak memberi keterangan secara ekplisit. Kitab Suci dan Tradisi diterima sebagai dua sumber dari iman seringkali tanpa membedakan antara Tradisi dan tradisi.

- Teologi ini memilih teologi skolastik yang diusulkan oleh St. Thomas Aquino: semua calon imam harus dikenalkan dengan teologi thomis.

- Sesuai dengan evolusi jaman, seringkali terdorong oleh keadaan guna mempertahankan iman, sentralisasi dalam pribadi paus merupakan sebuah keharusan. Paus dilihat sebagai satu-satunya garansi dan penjaga utama dari kebenaran iman. Dokumen-dokument kepausan (ensiklik dan keputusan-keputusan kuria Romana) memiliki bobot normatif.

- Teologi ini sangat mementingkan argumen dari teks-teks magisterium (paus) sebagai dasar refleksi teologisnya.

- Dengan menekankan definisi-definisi dan ajaran-ajaran yang dimengerti diluar konteksnya, kita memutus ajaran tersebut dari kehidupan iman Gereja dan pengalaman historis dimana rumusan ajaran itu berakar.

- Teologi ini cenderung untuk lebih mengabsolutkan konsep-konsep abstrak dan kurang memperhatikan pengalaman hidup beriman pada jaman baru.

- Kitab suci dipergunakan sebagai titik awal dari sebuah konstruksi rational dan sebagai sebuah referensi guna mendukung tesis-tesis yang sudah ada.

Disamping teologi resmi (cenderung dikontrol oleh Vatikan) muncullah sebuah aliran baru di banyak negara yang menginginkan sebuah pembaharuan dalam banyak bidang (Kitab Suci, Patristik, Liturgi, Eklesiologi, Keterbukaan terhadap dunia) $^{32}$. Pembaharuan-pembaharuan ini akan mempengarahui teologi yang akan diperdebatkan dan akan dibicarakan selama Konsili Vatikan II.

\section{a) Gerakan Biblis}

Meskipun pada awalnya, Gerakan pembaharuan biblis sedikit dicurigi, namun Ensiklik Divino 
afflante Spiritu (1943) memberi angin segar bagi studi biblis. Menurut Roger Aubert ${ }^{33}$, gerakan pembaharuan biblis diwarnai dengan tiga ciri : 1) penggunaan methode kritik sejarah, 2) tidak mereduksi exegese hanya kepada studi filologi dan archeologi tetapi lebih memunculkan makna religius dan teologis bagi umat kristiani, 3) menekankan arti literal (berseberangan dengan arti allegoris). Pembaharuan biblis ini menghasilkan banyak pembaharuan exegese sebagaimana terwujud dalam koleksi Lectio Devina, Biblische Studien (Fribourg im Brg), Alttestamentliche Abhandlungen und Neutesta,entliche Abhandlungen (Münster 1908-1931), La Revue Biblische Zeitschrift, La Dictionnaire de la Bible, etc.

\section{b) Studi Patristik}

Pembaharuan studi patristik menekankan pentingnya elaborasi teks original, membuat sebuah terjemahan yang setia dan sebuah penelitian teologi positif. Pembaharuan ini menghasilkan koleksi Patrologi Latin dan Patrologi Yunani (diterjemahkan dalam bahasa Prancis, Jerman, Spanyol, Inggris, Portugal), Corpus Christianorum, Clavis Patrum Latinorum, Clavis Patrum Graecorum, Sources chrétiennes, Library of the Father etc. Sebelum pembaharuan ini, orang mencari argumen patristik untuk mendukung teologi resmi; orang ingin membuktikan originalitas sebuah praktek liturgis atau sebuah ajaran. Pembaharuan studi patristik mencoba menggali teologi patristik dalam konteks aslinya, sebuah teologi yang menekankan hubungan misteri iman, sejarah keselamatan. Teologi patristik pertama-tama adalah komentar atas Kitab Suci.

\section{c) Gerakan Pembaharuan Liturgi}

Gerakan pembaharuan ini berawal di Jerman dan Austria. Di Prancis, pusat pastoral dan liturgi menjadi motor pembaharuan. Majalah La Maison de Dieu dan Lex orandi ikut membantu memperdalam gerakan ini dengan refleksi teologisnya. Gerakan ini dimotori oleh Dom Beauduin, Dom Festugière, Dom Casel. Gerakan ini menekankan partisipasi umat, perkembangan teologi tentang misteri Gereja dan tentang sakramen, dan sejarah keselamatan.

\section{d) Eklesiologi}

Sebelum Perang Dunia II, Adam Möhler dari Jerman memperkembangan sebuah eklesiologi yang memberi tempat istimewa kepada peranan Roh Kudus. Berkat studi-studi Kitab Suci dan patristic, para teolog semakin menyadari pentingnya pemahaman misteri Gereja dan Umat Allah untuk memberi keseimbangan baru bagi eklesiologi yang sangat menekankan segi juridis dan hirarkis. Para teolog besar seperti Y. Congar, K. Rahner, E. Schillebeeckx, G. Philips, etc ikut serta memperkaya eklesiologi jaman itu. Selain itu berkembang juga refleksi baru tentang peran para pelayan tertahbis khususnya para uskup. Dilain pihak, berkat berkembang pesatnya Action catholique yang menyentuh semua bidang kehidupan gereja (politik, sosial politik, ekonomi, rumah sakit, pendidikan dan paroki), lahirlah teologi tentang awam dan keterbukaan teologi katolik bagi hal-hal duniawi.

\section{e) Gerakan Ekumenisme}

Sejak berdirinya The World Council of Churches (WCC) di Amsterdam pada tahun 1948, gerakan ekumene, khususnya dikalangan gereja Reformasi, mendapatkan dinamika barunya. Sebelumnya gerakan Faith and Order (1910) dan gerakan Life and Work (1914) telah menjadi cikal bakal bagi WCC. Gerakan ini akan terus berkembang hingga hari ini. Sementara itu, Gereja katolik - meskipun tidak masuk menjadi anggota WCC karena bermacam-macam alasan -, turut serta secara aktif dalam gerakan ini. Dengan persetujuan dari paus Pius XI diadakanlah "percakapan Mechelen” antara Card. Mercier, Portal dan Halifax dari Anglikan (1921-1925). Paul Couturier memperkembangan kerasulan doa bagi persatuan Gereja-Gereja Kristus (18-25 januari). Dom Beauduin mendirikan sebuah biara Chevetogne (1925) yang mengkususkan diri bagi dialog antara Gereja katolik dan orthodoxe. Pada tahun 1960, paus Yohanes XXIII mendirikan secretariat untuk kesatuan seluruh umat Kristiani.

\section{Fransiskus Purwanto}

Program Studi Ilmu Teologi, Fakultas Teologi, Universitas Sanata Dharma, Yogyakarta;

Email:francis.pur@gmail.com

\section{CATATAN AKHIR}

1 Tulisan ini banyak mengikuti pemikiran P.Tihon, "L’Eglise”, in B. Sesboüé (ed.), Les Signes du Salut, Paris, Desclée, 1995 dan juga E. Ménard, 
L'ecclésiologi. Hier et aujourdh'hui, Paris, DDB, 1966.

2 Cf. E. Ménard, L'ecclésiologi. Hier et aujourdh'hui, Paris, DDB, 1966, 13-20; A.Fliche, La Réforme grégorienne, Louvain, Paris, Spic.sac.lov /Champion, 3 Vol, 1924, 1926, 1937 ; H.X. Arquillière, Saint Grégoire VII. Essai sur sa conception du pouvoir pontifical, Paris, Vrin, 1934 ; W. Ullmann, Medieval Papalism. The Pontifical Theories of Medieval Canonist, London, Methuen, 1949 ; The Growth of Papal Goverment in the Middle Ages. A Study in the Ideological relation of clerical to lay Power, London, Methuen, 1962; J. Rupp, L’idée pontificale de origines à Innocent III, Paris, Press Modern, 1939; M. Pacaut, La Théocratie. L'Eglise et le pouvoir au Moyen Âges, Paris, Desclée, 1989;

3 P.Tihon, "L’Eglise”, in B. Sesboüé (ed.), Les Signes du Salut, Paris, Desclée, 1995, 428

4 Y. Congar, L'Ecclésiologie du Haut Moyen Âge. De saint Grégoire le Grand à la désunion entre Byzance et Rome, Paris, Cerf, 1968, 107-112.

5 P.Tihon, “L’Eglise”, 430-433.

6 Y. Congar, L'Ecclésiologie du Haut Moyen Âge, 185-192.

7 M. Pacaut, La Théocratie. L'Eglise et le pouvoir au Moyen Âge, Paris, Desclée, 1989 ; H.X. Arquillère, L'Augustinisme politique. Essai sur la formation des théories politique au Moyen Âge, Paris, Vrin, 1934 ; J. Gaudemet, Eglise et Cité. Histoire du droit canonique, Paris, Cerf, 1994 ; P. Vallin, Les Chrétiens et leur histoire, Paris, Desclée, 1985.

8 E. Ménard, L'ecclésiologi, 20-22.

9 G. Sabra, Thomas Aquinas' Vision of the Church. Fundamentals of an Ecumenical Ecclesiology, Mainz, Grünewald, 1987; V. Martin, Les origines du gallicanisme, 2 vol., Paris, Bloud et Gay, 1939 ; J. Leclrecq,Jean de Paris et l'ecclésiologie du XIII siècle, Paris, Vrin, 1942.

10 P.Tihon, “L’Eglise”, 444-445.

11 STh III, q. 73, a.3., P.Tihon, “L’Eglise”, 447.

12 DzS 870-875

13 J. Courvoisier, De la Réforme au protestantisme. Essai d'ecclésiologie réformée, Paris, Beauchesne, 1977 ; H.J. Sieben, H.J., Die katholische Konzilsidee von der Reformation bis zur Aufklärung, Pederborn, Schöningh, 1988 ; A. Ganoczy, Calvin théologien de l'Eglise et du ministère, Paris, Cerf, 1964.

14 Phippe Melanchthon, La confession d'Augsbour et l'Apologie, trad. P. Jundt, paris, Cerf, 1989, art VII, 58-59.

15 COD II-2, h. 1351; DzS 1501-1505; FC 148-152.

16 Bulle Iunctum nobis 1564, DzS 1868.

17 Controverses III, 2 ; Opera Omnia, Paris Vivès, 1870, t.2, 317-318.

18 G.Thils, L'infallibilité du peuple chrétien «in credendo ». Notes de théologie postridentine, Paris, DDB, 1963 ; Les Notes de l'Eglise dans l'apologétique catholique depuis la Réforme, Gembloux, Duculot, 1937
19 Gregorius dari Valence SJ (1549-1603) mendefiniskan Gereja dan didalamnya ia tidak menyebutkan peran paus. Menurut Gregorius dari Valence, konsili hanyalah sebuah badan penasehat bagi paus, tanpa kuasa memutuskan. Francesco Suarez SJ (1548-1617) mengakui bahwa peran amat penting dari episkopal: secara hakikat institusional eklesial dapat dikatakan bahwa para uskup berbagi dengan paus memimpin Gereja. Ketika dipandang perlu untuk mengadakan konsili umum, konsili tersebut dapat diundang oleh collegialitas para kardinal atau keseluruhan uskup; jika paus menentangnya, orang harus tetap bertahan, karena paus menyalahgunakan kekuasaan. Luis Molina (1535-1600) mengakui bahwa hak untuk mengadakan sebuah konsili mengandaikan seorang paus yang benar : jika pada masa skisma terdapat keraguan terhadap ligitimitas paus, sebuah konsili dapat berkumpul tanpa persetujuannya ; dan jika seorang paus herisi, konsili dapat berkumpul melawan kehendak paus. Yohanes de SaintThomas OP (†1644) meneguhkan bahwa para uskup berkumpul dalam konsili, meskipun mereka tidak tergantung dari paus, mereka bukanlah wakilwakil paus, tetapi sebagai gembala Gereja yang benar.

20 G. Thils, L'infaillibilité du peuple chrétien in credendo. Notes de théologie postridentine, Paris, DDB, 1963 ; J. Lortz, Historie de l'Eglise des origines à nos jours, Paris, Payot, 1956; O. Rousseau, Histoire du mouvement liturgique. Esquisse historique depuis le début du XIX siècle jusqu'au pontificat de Pie X, Paris, Cerf, 1945.

21 M.de Certeau, L'Ecriture de l'histoire, Paris, Gallimard, 1975, 158 ; 161

22 A. Mayer-Pfannholz, «Der Wandel des Kirchenbildes in der Geschichte », Theologie und Glaube 33 (1941), 30.

23 Theol Quartalschrift 1823, 497, dikutip oleh Y. Congar, L'Eglise, 383.

24 L. Willaert, La Restauration catholique, Paris, Bloud et Gay, 1960 ; R. Aubert, « La Géographie ecclésiologique au xix siècele ", L'ecclésiologie au xix siècle, Paris, Cerf, 1960, 11-56 ; E. Hocedez, Histoire de la théologie au xix siècle, 3 vol, Bruxelles-Paris, Ed. Univ, 1947-1957 ; Y. Congar, "L'ecclésiologie de la Révolution française au concile du Vatican sour le signe de l'affirmation de l'autorité ", L'ecclésiologie au xix siècle, Paris, Cerf, 1960. J.A. Möhler, L'unité dans l'Eglise ou le principe du catholicisme d'après l'esprit des Pères des trois siècle, Paris, Cerf, 1938 ; Symbolik oder Darstellung $d r$ dogmatischen Gegensätze der Katholiken und Protestanten nach ihren öffentlichen Bekenntnisschriften, hggb von J.R. Geiselmann, 2 vol, Köln, Hegner, 1958 ; J.H. Newman, Essaie sur le développement de la doctrine chrétienne, Paris, Cerf, DDB, 1964 ; Pensée sur l'Eglise, Paris, Cerf, 1956, F. Purwanto, Ecclesiologie dans l'oeuvre de Gustave Thils, Louvain-La-Neuve, 2006 (tesis). 
25 Du Pape, I,1 ; Euvres, Lyon, Vitte, 1892, t.2, 2.

26 Symbolique, par 36, trad. Lachat, Bruxelles, Fontteyn, 1854, t.2, 8-9.

27 H. Fries, Wandel des Kirchenbildes, 269-271; Thils, G., La Primauté pontificale. La doctrine de Vatican I, les voies d'une révision, Gembloux, Duculot, 1972.

28 Cf. A. Dondeyne, La foi écoute le monde, Paris, Ed. Universitaire, 1964, 29-35

29 Cf. R. Winling, La théologie contemporaine (19451980), Paris, Centurion, 1983 p. 21-27; R. Verneaux, Histoire de la philosophie contemporaine, Paris, Beauchesne, 1960, 151-190.

30 Cf. Roger Aubert, L'Église Catholique de la crise de 1848 à la Première Guerre Mondiale, dans Nouvelle Histoire de l'Église (sous dir. R. Aubert), t. V, Paris, Seuil, 1975, 201

31 Cf. Winling, R., La théologie contemporaine ..., 60-68

32 Cf. E. Vilanova, Histoire des théologies chrétiennes, t.3, Paris, Cerf, 1997 ; Vander Gucht, R. - Vorgrimler, H. (dir.), Bilan de la théologie du XXe siècle, t.1-2, Tournai/Paris, Casterman, 1975

33 Cf. R. Aubert, La théologie catholique a milieux du XXe siècle, Cerf, Tournai, 1954, 11-28

\section{DAFTAR RUJUKAN}

Alberigo, G. (éd.), 1995-2004, History of Vatican II, Vol. I-V, Orbis, Maryknoll.

Alberigo, G., (éd.) , 1986, Synod 1985 - An Evaluation, Concilium.

Aubert, R., «Les étapes de l’œcuménisme catholique depuis le pontificat de Léon XIII jusqu'à Vatican II », 1968, La Théologie du renouveau, t.1, Cerf, Paris.

Aubert, R. , 1954, La théologie catholique a milieux du XXe siècle, Cerf, Tournai.

Auubert, R. , 1975, L'Église Catholique de la crise de 1848 à la Première Guerre Mondiale, dans Nouvelle Histoire de l'Église (sous dir. R. Aubert), t. V, Seuil, Paris.

Congar, Y. - Dupuy, B. , 1962 (ed.), L'épiscopat et L'Eglise universelle, Cerf, Paris.

Congar, Y, 1982., Essais øcuméniques, Cerf, Paris.

Congar, Y. , 1968, L’Ecclésiologie du Haut Moyen Âge. De saint Grégoire le Grand à la désunion entre Byzance et Rome, Cerf., Paris

Congar, Y, 1985., Le Concile Vatican II. Son Eglise. Peuple de Dieu et Corps du Christ, Beauchesne, Paris.

De Certeau, M. , 1975, L'Ecriture de l'histoire, Gallimard, Paris.

Denzinger, H. , 1997, Symboles et Définitions de la Foi Catholique (trad. Française J. Hoffmann), Cerf, Paris.
De Lubac, H. , 1938, Catholicisme. Aspects sociaux du Dogme, Cerf, Paris.

Dondeyne, A. , 1964, La foi écoute le monde, Ed. Universitaire, Paris.

Famerée, J. , 1992, L'Ecclesiologie d'Yves Congar avant Vatican II. Histoire et Eglise. Analyse et reprise critique, Leuven, University Press.

Godin H., et Yvan Daniel, 1943, France, pays de mission ? Cerf, Paris.

Jacobs, T. , 1974, Lumen Gentium, Jilid I-III, Kanisius, Jogjakarta.

Jáki, S. , 1957, Les tendances nouvelles de l'ecclésiolo gie, Herder, Roma.

Kirchberger G., - J.M. Prior, 2003, Konsili Yohanes XIII. Berpancawindu, 19622002, Ledalero, Maumere.

Kirchberger, G. , 1991, Gereja Yesus Kristus Sakramen Roh Kudus, Arnoldus, Ende.

Kloppenburg, B. , 1974, The Ecclesiology of Vatican II, Franciscan Herald, Chicago.

Kress, R. , 1985, The Church: Communion, Sacrement, Communication, Paulist Press, NY.

L. Bouyer, 1982, The Church of God, Fransciscan Herald, Chicago.

Lamb, M.L. - M.Levering, 2008, Vatican II. Renewal within Tradition, Ofxord Press, Oxford.

Latourelle, R. , 1989, (éd.), Vatican II. Assessment and Perspectives. Twenty-five Years After (1962-1987), Vol. I-III, Paulist Press, NY.

Martimort, A.G. , 1946, De l'éveque, Cerf, Paris.

Ménard, E. , 1966, L'ecclésiologi. Hier et aujourdh'hui, DDB, Paris.

Moeller, C. , 1966, Le ferment des idées dans l'élaboration de la Constitution, in Barauna, G. - Congar, Y., L'Eglise de Vatican II. Etudes autour de la Constitution concilaire sur l'Eglise, t. 2, Cerf, Paris.

Phan, P.C. , 1970, (éd.), The Gift of the Church, Minnesota, Liturgical Press, 2000. J.Ratzinger, Puntjak-Puntjak Teologis dalam Konsili Vatikan II, Kanisius, Jogjakarta.

Prignon, A. , 1996, Evêques et théologiens de Belgique au concile Vatican II, in Soetens, C. (dir), Vatican II et la Belgique, Louvain-la-Neuve, Arca.

Purwanto,F. , 2006, L'Ecclesiologie dans l'oeuvre de Gustave Thils, Louvain-La-Neuve (tesis).

Rausch, T.P. , 1993, Towards a Truly Catholic Church, Liturgical Press., Minnesota 
Thils, G. , 1963, L'infallibilité du peuple chrétien « in credendo». Notes de théologie postridentine, DDB, Paris.

Thils, G. , 1972, La Primauté pontificale. La doctrine de Vatican I, les voies d'une révision, Duculot, Gembloux.

Tihon, P. "L’Eglise” , 1995, in B. Sesboüé (ed.), Les Signes du Sal, Desclée ut, Paris.
Verneaux, R. , 1960, Histoire de la philosophie contemporaine, Beauchesne, Paris.

Vilanova, E. , 1997, Histoire des théologies chrétiennes, t.3, Cerf, Paris.

Willaert, L. , 1960, La Restauration catholique, Bloud et Gay, Paris.

Winling, R., 1983, La théologie contemporaine (1945-1980), Centurion, Paris.

Thils, G., 1937, Les Notes de l'Eglise dans l'apologétique catholique depuis la Réforme, Gembloux, Duculot.

Vander Gucht, R. - Vorgrimler, H. (dir.) , 1975, Bilan de la théologie du XXe siècle, t.1-2, Casterman, Tournai /Paris. 